\title{
Differences in Entrepreneurial Skills of College Students in the Mexican Intercultural Context
}

\author{
Marco Alberto Nuñez Ramírez ${ }^{1}$, Teodoro Rafael Wendlandt Amezaga ${ }^{1}$, María Trinidad Álvarez Medina ${ }^{2}$ \& \\ Jorge Ortega Arreola ${ }^{1}$ \\ ${ }^{1}$ Department of Management, Instituto Tecnológico de Sonora, Sonora, México \\ ${ }^{2}$ Department of Accounting and Finance, Instituto Tecnológico de Sonora, Sonora, México \\ Correspondence: Teodoro Rafael Wendlandt Amezaga, Department of Management, Instituto Tecnológico de \\ Sonora, Calle 5 de febrero No. 818 sur, Sonora, C.P. 85000, Ciudad Obregón, Sonora, México. E-mail: \\ teodoro.wendlandt@itson.edu.mx
}

Received: May 7, 2016

doi:10.5539/ijbm.v11n 7 p120
Accepted: May 26, 2016

Online Published: June 18, 2016

\begin{abstract}
The purpose of this study is to describe the development of entrepreneurial skills of college students in the intercultural context of Mexico. By a non-probability sampling method, a sample of 120 students from an intercultural institution of higher education in the Southeastern Mexico was selected, from which two groups (Indigenous and Mestizos) were obtained to perform the corresponding statistical analyses. The first group was integrated by indigenous students $(n=55)$ and the second group by mestizos $(n=65)$. For data analysis, the Student $t$ test and one-way analysis of variance (ANOVA) were used. The results showed no significant differences in the entrepreneurial skills between both groups. However, significant differences were obtained when considering the educational programs offered by the intercultural institution, where the program in sustainable rural development was the one that obtained a higher level regarding the development of entrepreneurial skills. This research contributes with empirical evidence to the knowledge on interculturality in this country.
\end{abstract}

Keywords: culture, entrepreneurial skill, college student, intercultural, Mexico

\section{Introduction}

There is a prevalent concept that entrepreneurship might be a key element for the economic development of nations (Kets de Vries, 1996; Lazear, 2005; McMullen, 2011; Peredo \& McLean, 2013; Sautet, 2013; Shane \& Venkataraman, 2000; World Bank, 1995), this is the reason why interest on the study of entrepreneurship and its characteristics have increased in the last decades (Venkataraman, 1998). As a result, besides its economic and social impacts, it is possible to notice the emergence of a great number of business organizations around the globe (Duarte \& Ruiz, 2009; Drucker, 2015).

Nevertheless, despite entrepreneurship has turned into a relevant topic in social sciences, academic literature notes the lack of a general conceptual structure on this variable (Shane \& Venkataraman, 2000; Yamada, 2004); in such a way that nowadays still doesn't exist a fully accepted definition of entrepreneurship (Gartner, 1988; Henry, Hill, \& Leitch, 2005). However, it is possible to identify two basic perspectives or postures: the first one is oriented towards the organizational environment, where it is perceived as the capacity of innovating (McClelland, 1961; Schumpeter, 1950); while the second one refers to the ability to create a new business (Kets de Vries, 1985; Radziszewska, 2014; Venkataraman, 1998). This second perspective is precisely the one chosen as a reference for this study.

In consideration of the latter approach, the entrepreneur may be seen as an independent person who is capable to organize people and the necessary resources for the creation of businesses (Radziszewska, 2014); i.e., it is the person who founds a new business with the plan of making it grow through self-employment, management and coordination, as well as decision making related to the use of time, effort and money (Kets de Vries, 1985; Shane \& Venkataraman, 2000; Venkataraman, 1998).

However, there is some controversy regarding the differences between those who are entrepreneurs and those who are not (Shane \& Venkataraman, 2000). According to Mueller, Volery, and Von Siemens (2012), one way to 
understand the entrepreneur is through his behavior, which plays an important role in relation with discovering, evaluating and exploiting the opportunities of one business idea. In this respect, Kets de Vries $(1985 ; 1996)$ found that the personality of entrepreneurs is characterized by certain functional aspects that define them, which are known as entrepreneurial skills.

The entrepreneurial skills are defined as a set of abilities and attitudes that enable a person to start a business (Shane \& Venkataraman, 2000), where its emphasized the permanent intention of managing resources to generate results according to the activity which is being performed (Quintero, 2007); the achieving of high levels of life and labor satisfaction (Blanchflower \& Oswald, 1998), as well as the search of a benefit through individual or group work, and the identification of opportunities and innovation (Lazear, 2005). Considering these ideas, Tinoco (2008) proposes a taxonomy on such variable based on self-knowledge and a vision of the future (Kets de Vries, 1996), achievement motivation (McClelland, 1961), planning (Venkataraman, 1998), and persuasion (Yamada, 2004).

Based on the definition above, the study of entrepreneurial skills just begins to develop both conceptually and methodologically (Brazeal \& Herbert, 1999, cited in Henry et al., 2005; Gartner, 1998; Shane \& Venkataraman, 2000); and even more so when studying them within the context of native or indigenous peoples, where culture plays a determinant role (Morley, 2014; Peredo \& McLean, 2013). It is worth mentioning that the theoretical and empirical evidence on the research of such variable within the intercultural context is almost non-existent (Dana \& Anderson, 2007).

It should be noted that the study of entrepreneurship could be approached from different levels of analysis, where it is necessary to consider the social and cultural context (Yamada, 2004). For its part, culture certainly plays an important role in the capacity to undertake a business (Hofstede, Hofstede, \& Minkov, 2010; Lounsbury \& Glynn, 2001; Peredo \& McLean, 2013; Radziszewska, 2014; Yetim \& Yetim, 2006), which is partly because the creation and development of business must be based on the needs and expectations of their own communities and its cultural characteristics (Marín, 2015), which are diversified and become intercultural by means of the social interaction.

When referring to entrepreneurship within a particular cultural context, it is necessary to refer to the native entrepreneurship, since this is a potential instrument to counteract the endemic impoverishment suffered by indigenous peoples (Peredo \& McLean, 2013). Thereon, Begley and Tan (2001) found that the cultural and social contexts influence on a different level of interest to entrepreneurs in countries of Western Asia, which differs from Anglo-Saxon countries; such findings provide empirical evidence that validates the hypothesis of cultural differences between these countries, this in addition to the studies of Hofstede (1980) who found that Western Asia countries are distinguished by having a collectivist culture different from the more individualistic cultural characteristics of the Anglo-Saxon nations.

Taking into account that most of the members of the indigenous peoples around the world possess high levels of poverty, low levels of education and limited access to health services (Peredo, Anderson, Galbraith, Honig, \& Dana, 2004), entrepreneurship should be considered -through the realities of different cultures- as an instrument that impulse the development of the indigenous communities (Peredo \& McLean, 2013); this because the concept of entrepreneurship has been built not only through the economic approach, but also the cultural one (European Union, 2012).

It is therefore necessary to promote the creation of companies -especially in the most vulnerable contexts-, since the promotion of the entrepreneurship can be considered a strategy to counteract the high poverty conditions in these indigenous communities (Hindle \& Moroz, 2009; Marín, 2015; Peredo \& McLean, 2013), which could constitute a means of protection against the exclusion and disadvantages of the labor market (Rodríguez, Sánchez, \& Estévez, 2011). It is important to note that this strategy has shown positive results in some countries such as Australia, where in two decades (1991-2011) the number of indigenous entrepreneurs increased nearly 300 per cent (Hunter, 2013, cited in Morley, 2014).

It is important to point out that there are few international studies on indigenous entrepreneurship (Apaza \& Moreno, 2008; Furneaux \& Brown, 2007; Westpac Group, 2014); notable among these are Furneaux and Brown (2007) who found in Australia that the average creation of new companies by the indigenous people was lower than Caucasians, as well as Apaza and Moreno (2008) in Peru, who studied dairy companies, community-based tourism, and women engaged in handicrafts.

In the case of Mexico, the theme of indigenous entrepreneurship also has been scarcely researched, being few the studies that provide empirical evidence on the matter (Barba-Sánchez \& Molina, 2015; Rodríguez et al., 2011; Torres \& Anderson, 2007). Among the few studies it is possible to mention to Torres and Anderson (2007), who 
investigated a Mayan agro-ecological center in the state of Chiapas; Barba-Sánchez and Molina (2015), who studied entrepreneurs of ecotourism businesses of central and southeast Mexico; and finally Rodríguez et al. (2011), who studied women entrepreneurs of Nahuatl origin. It is clear that such evidence is not enough to understand this multicultural country, which has a population of 16 million people considered as members of some indigenous group (Marín, 2015), -the greatest indigenous population of America according to Schmelkes (2013)- where coexist 68 ethno-linguistic groups that comprise 264 dialectal variants (Instituto Nacional de Lenguas Indígenas, 2009).

Consequently, in the case of Mexico it is necessary to go beyond the simple indigenous entrepreneurship and focus on intercultural entrepreneurship, where economical growth is promoted through the interaction between different cultures. It should be noted that the intercultural approach is the one which promotes the acknowledgment of the person and the validation of others (Organización Panamericana de la Salud, 2008), the respect for cultural diversity and for the rights of indigenous people (Ávila, 2011), the coexistence of different cultures (Dietz \& Mateos, 2011), and the promotion of differences (Barriga-Villanueva, 2008; Flores-Crespo \& Barrón, 2006). Likewise, through dialogue, the multiculturalism allows people to acquire values that determine how they see themselves and how to perceive the world, taking as a basis the respect and appreciation for the others -despite their cultural differences- (Schmelkes, 2003).

Considering that cultural differences have a significant influence on entrepreneurial behavior of members of a particular community -and even more in the intercultural context- (Berkes \& Adhikari, 2006; Radziszewska, 2014; Petrakis \& Kostis, 2014; Yamada, 2004), and also that the creation and development of enterprises is based on the needs and expectations of their own communities and their cultural characteristics (Marín, 2015); then it is possible to state the following research question: What differences exist in the development of entrepreneurial skills when comparing two groups of intercultural students (Indigenous and Mestizos)?

Reference to intercultural students is made from the context of interaction between different cultures that exist in Mexico, within the educational model of intercultural universities emerged in 2003 (Sandoval-Forero \& Guerra-García, 2007). Mexican universities that adopt this model, offer educational programs whose purpose is to promote the development of indigenous peoples through the learning of scientific knowledge and its integration with the ancestral knowledge, besides the generation of productive and self-managed projects (González, 2007). Additionally, this model also pretends to avoid segregation of individuals and to promote a culture of respect for the differences among people (Flores-Crespo \& Barrón, 2006).

According to Dietz and Mateos (2011), through this model and its pedagogical approach different from the traditional (Western model) -which leverages the heterogeneity of classrooms and aims to the empowerment of individuals-, it has sought to generate entrepreneurs to support indigenous communities. Moreover, Sandoval-Forero and Guerra-García (2007) mention that intercultural universities represent a different didactic application by considering and leveraging the natural, social and cultural context of each one of the ten states where such institutions of higher education are established (Chiapas, Estado de México, Guerrero, Michoacán, Puebla, Quintana Roo, San Luis Potosí, Sinaloa, Tabasco, and Veracruz), and offer a variety of undergraduate programs of different academic disciplines (medical, social, agro-industrial, managerial, pedagogical, and communication sciences).

Finally, González (2007) adds that the common target of all these educational programs is to promote the community development through the generation of productive projects, which in turn requires the development of entrepreneurial skills for it; this on the basis that developing entrepreneurship comes from its promotion within the institutions of higher education (Achtenhagen \& Knyphausen-Aufsess, 2008). This leads to a second research question: What differences exist in the development of entrepreneurial skills of intercultural students when considering different undergraduate programs (Tourism development, Sustainable rural development, Intercultural nursing, Language and culture, and Intercultural communication)?

As possible answers to the previous research questions, the next two hypotheses are established:

$H_{1}$ : There are significant differences in the development of entrepreneurial skills when comparing two groups of intercultural students (Indigenous and Mestizos).

$\mathrm{H}_{2}$ : There are significant differences in the development of entrepreneurial skills of intercultural students when considering different undergraduate programs (Tourism development, Sustainable rural development, Intercultural nursing, Language and culture, and Intercultural communication).

\section{Method}

This study utilizes a quantitative research approach, whose scope can be classified as descriptive and 
comparative (Creswell, 2014; Hernández, Fernández, \& Baptista, 2014). By means of a non-probabilistic sample, 120 undergraduate students from an intercultural university in a southeastern state of Mexico participated in the investigation. The main characteristics of these participants are described in Table 1.

To achieve the study's purpose, the measurement instrument utilized was composed of two parts, the first related to the sociodemographic data and the second by the scale of entrepreneurial skills proposed by Tinoco (2008). Regarding this scale, a total of 20 questions were shown whose answers were collected by a Likert-type scale with five options to respond, varying from 1 (Never) to 5 (Always). Furthermore, this scale was constituted by five factors or subdimensions (self-knowledge, vision of the future, achievement motivation, planning, and persuasion), which resulted with an acceptable internal consistency (reliability $\geq .70$ ) by means of the Cronbach

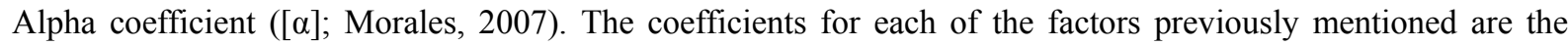
following: Self-knowledge $(\alpha=.72)$, Vision of the future $(\alpha=.70)$, Achievement motivation $(\alpha=.72)$, Planning $(\alpha=.70)$, and persuasion $(\alpha=.71)$.

For the application of the instrument, the proper permission of the university authorities was requested and obtained. Subsequently, students were invited to participate in the study voluntarily and always guaranteeing the confidentiality of the information provided by them. Once collected the sample data, the program SPSS (version 22) was used for the statistical analysis (Student's $t$ test, One-Way Analysis of Variance [ANOVA], Post-Hoc comparisons) of the information.

Table 1. Characteristics of the college students participating in the study $(N=120)$

\begin{tabular}{|c|c|c|}
\hline Characteristics & $n$ & $\%$ \\
\hline \multicolumn{3}{|l|}{ Age (years) } \\
\hline $17-21$ & 86 & 72 \\
\hline $22-26$ & 25 & 20 \\
\hline$\geq 27$ & 9 & 8 \\
\hline \multicolumn{3}{|l|}{ Gender } \\
\hline Male & 52 & 43.3 \\
\hline Female & 68 & 56.7 \\
\hline \multicolumn{3}{|l|}{ Birthplace (State) } \\
\hline Tabasco & 64 & 53.3 \\
\hline Chiapas & 63 & 46.7 \\
\hline \multicolumn{3}{|l|}{ Native language speaker } \\
\hline Yes & 55 & 45.8 \\
\hline No & 65 & 54.2 \\
\hline \multicolumn{3}{|l|}{ Name of the native language } \\
\hline Ch'ol & 40 & 72.7 \\
\hline Zoque & 12 & 21.8 \\
\hline Tzotzil & 2 & 3.7 \\
\hline Chontal & 1 & 1.8 \\
\hline \multicolumn{3}{|l|}{ Educational programs } \\
\hline Tourism development & 27 & 22.5 \\
\hline Sustainable rural development & 15 & 12.5 \\
\hline Intercultural nursing & 55 & 45.8 \\
\hline Language and culture & 17 & 14.2 \\
\hline Intercultural communication & 6 & 5 \\
\hline
\end{tabular}

Note. Own elaboration.

\section{Results}

To test the research hypotheses, it was decided that the most appropriate statistical models were the Student's $t$ test and one-way ANOVA. The independent $t$ test to evaluate the difference between the means of two independent groups ([Indigenous and Mestizos] Ho, 2014), and the one-way ANOVA was used to know whether the means of several independent groups differ ([undergraduate programs] Hernández et al., 2014).

First, the study findings did not provide support for $\mathrm{H}_{1}$ because no significant differences were found regarding the entrepreneurial skills when comparing two groups of intercultural students -Indigenous and Mestizos- (see 
Table 2). These results contradict what has been pointed out by Hofstede (1980), Yamada (2004), Berkes and Adhikari (2006), and Radziszewska (2014), for whom the cultural differences have a significant influence on the behaviors to generate new businesses; such is the case of entrepreneurial skills. Although it is not possible to generalize this result, the empirical evidence suggests that within the intercultural context, both the people who are part of some indigenous people -whether it is ch'ol, zoque, tzotzil or chontal- and mestizos, do not differ in terms of their abilities to generate business.

Table 2. Comparison of groups with regard to entrepreneurial skills $(N=120)$

\begin{tabular}{|c|c|c|c|c|c|c|c|c|}
\hline \multirow[b]{2}{*}{ Entrepreneurial skills } & \multicolumn{2}{|c|}{$\begin{array}{l}\text { Indigenous group } \\
\quad(n=55)\end{array}$} & \multicolumn{2}{|c|}{$\begin{array}{l}\text { Mestizo group } \\
\quad(n=65)\end{array}$} & \multirow[b]{2}{*}{$d f$} & \multirow[b]{2}{*}{$t$} & \multirow[b]{2}{*}{$p$} & \multirow[b]{2}{*}{ Cohen's $d$} \\
\hline & $M$ & $S D$ & $M$ & $S D$ & & & & \\
\hline Self-knowledge & 4.00 & 0.64 & 3.97 & 0.74 & 118 & 0.282 & .188 & 0.051 \\
\hline Vision of the future & 3.90 & 0.57 & 3.85 & 0.75 & 118 & 0.416 & .237 & 0.076 \\
\hline Achievement motivation & 4.04 & 0.58 & 4.13 & 0.65 & 118 & -0.788 & .114 & -0.014 \\
\hline Planning & 3.96 & 0.61 & 4.04 & 0.62 & 118 & -0.689 & .874 & -0.126 \\
\hline Persuasion & 3.49 & 0.78 & 3.55 & 0.76 & 118 & -0.386 & .468 & -0.071 \\
\hline
\end{tabular}

Note. Own elaboration.

Second, there were found significant differences in the development of entrepreneurial skills of intercultural students when considering different undergraduate programs (see Table 3 in Appendix), these are: self-knowledge $(F=2.45, p=.050)$, achievement motivation $(F=2.79, p=.029)$, and planning $(F=2.55, p$ $=.043)$. This result provides partial support to $\mathrm{H}_{2}$. It is worth noting that among the different undergraduate programs, the program of sustainable rural development obtained the higher values within the entrepreneurial skills of self-knowledge $(M=4.46, S D=0.39)$, achievement motivation $(M=4.48, S D=0.53)$, and planning $(M$ $=4.41, S D=0.45)$; this was also confirmed in the Post-hoc test, where findings suggest this prevalence of sustainable rural development over tourism development and intercultural nursing (see Table 4).

Table 3. Mean scores on five entrepreneurial skills as a function of the educational programs

\begin{tabular}{|c|c|c|c|c|c|c|c|c|c|c|c|}
\hline \multirow[b]{3}{*}{ Entrepreneurial Skills } & \multicolumn{10}{|c|}{ Educational programs } & \multirow[b]{3}{*}{ Post hoc } \\
\hline & \multicolumn{2}{|c|}{$\begin{array}{c}\text { Tourism } \\
\text { development (1) }\end{array}$} & \multicolumn{2}{|c|}{$\begin{array}{l}\text { Sustainable rural } \\
\text { development (2) }\end{array}$} & \multicolumn{2}{|c|}{$\begin{array}{c}\text { Intercultural } \\
\text { nursing } \\
(3)\end{array}$} & \multicolumn{2}{|c|}{$\begin{array}{c}\text { Language and } \\
\text { culture (4) }\end{array}$} & \multicolumn{2}{|c|}{$\begin{array}{c}\text { Intercultural } \\
\text { communication (5) }\end{array}$} & \\
\hline & $M$ & $S D$ & $M$ & $S D$ & $M$ & $S D$ & $M$ & $S D$ & $M$ & $S D$ & \\
\hline Self-knowledge & 3.87 & 0.52 & 4.46 & 0.39 & 3.88 & 0.78 & 4.07 & 0.76 & 4.04 & 0.58 & $2>3$ \\
\hline Vision of the future & 3.76 & 0.62 & 4.25 & 0.36 & 3.81 & 0.78 & 3.89 & 0.56 & 4.04 & 0.46 & - \\
\hline Achievement motivation & 3.88 & 0.54 & 4.48 & 0.53 & 4.02 & 0.69 & 4.25 & 0.47 & 4.12 & 0.52 & $2>1$ \\
\hline Planning & 3.86 & 0.64 & 4.41 & 0.45 & 3.93 & 0.64 & 4.13 & 0.52 & 4.04 & 0.51 & $2>1,3$ \\
\hline Persuasion & 3.32 & 0.63 & 3.81 & 0.49 & 3.50 & 0.85 & 3.63 & 0.87 & 3.62 & 0.77 & - \\
\hline
\end{tabular}

Note. The numbers in parentheses in column heads refer to the numbers used for illustrating significant differences in the "Post hoc" column. For all measures, higher means indicate higher entrepreneurial skills. The comparison of means was performed using the Bonferroni method. The differences were significant at $p<.05$.

\section{Conclusion}

It should be considered that the development of entrepreneurship around the world is partly due to its promotion in the institutions of higher education (Achtenhagen \& Knyphausen-Aufsess, 2008). In this sense, one of the main objectives of the intercultural universities -institutions that seek to counteract the social inequality and poverty of the members of the indigenous peoples of Mexico (Guitart \& Rivas, 2008)-, has been to develop the entrepreneurial skills of the people living in the regions where there is interaction between different cultures. Taking in consideration this particular context, the study aimed to describe the development of entrepreneurial skills of college students in the intercultural context of Mexico.

The results provide empirical evidence that suggests that there are no differences in these skills among individuals who are part of some indigenous people and mestizos. Such findings contradict the ideas proposed by 
Hofstede (1980), Yamada, (2004), Berkes and Adhikari (2006), Peredo and Anderson, (2006), Peredo and McLean (2013), Westpac Group (2014), and Radziszewska (2014), for whom culture affects the development of the behavior of entrepreneurs. However, it is possible that the results are being affected by the lack of representativeness of the sample (sample size) and the sampling method (non-probability sample), which could be only discarded through new investigations of the intercultural groups to confirm these findings in Mexico.

Furthermore, to achieve the purpose of training entrepreneurs in the intercultural universities -mainly in the indigenous regions of Mexico-, it is necessary to involve other actors such as the communities themselves and the government. There is also necessary to underline that the economic development of the indigenous peoples is most successful when it is led by the communities themselves, being many the opportunities through which governments can contribute to the businesses' success in these regions (Westpac Group, 2014).

For forthcoming investigations could be relevant to study the relationship and involvement of the community and the government as promoters of the intercultural entrepreneurship, this under the perspective of the intercultural social capital. Moreover, could be considered the networks between the business of the members of indigenous peoples and others that are not, since these networks apparently favor regional entrepreneurship and community development. Finally, for future studies, it is recommended to use several versions of the measuring instrument according to the languages of the participants, this because for many of the persons in the study their mother tongue is not Spanish.

Globalization has made it possible to carry out a closer contact between different cultures, resulting in a greater intercultural dialog that involves the interaction of attitudes, behaviors, knowledge and skills (United Nations Educational, Scientific and Cultural Organization, 2013). This enables intercultural entrepreneurship, which allows the economic and social development of the indigenous groups that decide to undertake new businesses due to the lack of employment opportunities (Rodríguez et al., 2011). The present study represents a starting point for further research under this approach in intercultural groups, where theoretical and empirical evidence remains very scarce.

\section{Acknowledgments}

This research was supported by the Instituto Tecnológico de Sonora trough the "Program for the Support and Development of Research Projects" (PROFAPI, by its Spanish acronym).

\section{References}

Achtenhagen, L., \& Knyphausen-Aufsess, D. Z. (2008). Fostering doctoral entrepreneurship education in Germany. Journal of Small Business and Enterprise Development, 15(2), 397-404. http://dx.doi.org/10.1108/14626000810871754

Apaza, R. F., \& Moreno, S. (2008). ¿Qué es el Programa Modular: Emprendimientos para pueblos Indígenas? [What is the Modular Program: Enterprises for Indigenous Peoples?]. Lima, Perú: Organización Internacional del Trabajo-Centro Internacional de Formación (in Spanish). Retrieved from http://intranet.oit.org.pe/WDMS/bib/virtual/coleccion_oit/libros/programa_modular_eppi.pdf

Ávila, A. (2011). Universidades interculturales y colonialidad del saber [Intercultural Universities and Coloniality of Knowledge]. Revista de Educación y Desarrollo, 16, 19-26. Retrieved from $\mathrm{http}: / /$ www.cucs.udg.mx/revistas/edu_desarrollo/anteriores/16/016_Avila.pdf

Barba-Sánchez, V., \& Molina, E. (2015). Efectos del apoyo emocional de las redes cercanas al emprendedor indígena sobre el éxito de la nueva empresa ecoturística en la mitad sur de México [Effects of emotional support from nearby networks to indigenous entrepreneurs on the success of the new ecotourism business in the southern half of Mexico]. Cuadernos de Turismo, 36(2), 79-99. http://dx.doi.org/10.6018/turismo.36.230891

Barriga-Villanueva, R. (2008). Miradas a la interculturalidad. El caso de una escuela urbana con niños indígenas [Glances to interculturality. The case of an urban school with indigenous children]. Revista Mexicana de Investigación Educativa, 13(39), 1229-1254. $\quad$ Retrieved from http://www.comie.org.mx/v1/revista/portal.php?idm=es\&sec=SC03\&\&sub=SBB\&criterio=ART39008

Begley, T. M., \& Tan, W. L. (2001). The Socio-Cultural Environment for Entrepreneurship: A Comparison between East Asian and Anglo-Saxon Countries. Journal of International Business Studies, 32(3), 537-553. Retrieved from http://www.jstor.org/stable/3069496

Berkes, F., \& Adhikari, T. (2006). Development and conservation: indigenous businesses and the UNDP Equator Initiative, International Journal of Entrepreneurship and Small Business, 3(6), 671-690. 
http://dx.doi.org/10.1504/IJESB.2006.010920

Blanchflower, D. G., \& Oswald, A. J. (1998). What Makes an Entrepreneur? Journal of Labor Economics, 16(1), 26-60. Retrieved from http://www.andrewoswald.com/docs/entrepre.pdf

Brazeal, D. V., \& Herbert, T. T. (1999). The Genesis of Entrepreneurship, Entrepreneurship Theory and Practice, 23(3), 29-45.

Creswell, J. W. (2014). Research Design: Qualitative, Quantitative, and Mixed Methods Approaches (4th ed.). Thousand Oaks, California, USA: SAGE Publications, Inc.

Dana, L.-P., \& Anderson, R. B. (2007). International Handbook of Research on Indigenous Entrepreneurship. Cheltenham, United Kingdom: Edward Elgar Publishing Limited. Retrieved from http://www.untag-smd.ac.id/files/Perpustakaan_Digital_1/ENTREPRENEURSHIP\%20International\%20Ha ndbook\%20of\%20Research\%20on\%20Indigenous\%20entrepreneurship.pdf

Dietz, G., \& Mateos, L. S. (2011). Interculturalidad y Educación Intercultural en México: Un análisis de los discursos nacionales e internacionales en su impacto en los modelos educativos mexicanos [Interculturality and Intercultural education in Mexico: An analysis of the national and international speeches in its impact on the Mexican educational models]. México, D. F.: Secretaría de Educación Pública/Coordinación General de Educación Intercultural y Bilingüe.

Drucker, P. (2015). Innovation and Entrepreneurship: Practice and Principles. New York, USA: Routledge Classics.

Duarte, T., \& Ruiz, M. (2009). Emprendimiento, una opción para el desarrollo [Entrepreneurship, an option for the development]. Scientia Et Technica, 15(43), 326-331. Retrieved from http://www.redalyc.org/articulo.oa?id=84917310058

European Union (2012). Entrepreneurship determinants: culture and capabilities. Luxembourg, Belgium: Publications Office of the European Union. http://www.dx.doi.org/10.2785/29545

Flores-Crespo, P., \& Barrón, J. C. (2006). El programa de apoyo a estudiantes indígenas: ¿Nivelador académico o impulsor de la interculturalidad? [The program of support to indigenous students: Academic regulator or driver of the interculturality?]. México, D.F.: Asociación Nacional de Universidades e Instituciones de Educación Superior $\quad$ (ANUIES). Retrieved from http://publicaciones.anuies.mx/libros/69/el-programa-de-apoyo-a-estudiantes-indigenas-nivelador-academic o-o

Furneaux, C., \& Brown, K. (February, 2007). Indigenous Entrepreneurship: An Analysis of Capital Constraints. Conference paper presented in the Fourth AGSE International Entrepreneurship Research Exchange, Brisbane, Australia. Retrieved from http://eprints.qut.edu.au/12947/

Gartner, W. B. (1988). "Who Is an Entrepreneur?" Is the Wrong Question. American Journal of Small Business, $12(4), 11-32$.

González, F. (2007). Cultura y desarrollo desde la interculturalidad. Breve recuento de la primera universidad intercultural de México [Culture and development from interculturality. Brief account of the first Intercultural University of Mexico]. $R a$ Ximhai, 3(2), 243-272. Retrieved from http://www.ejournal.unam.mx/rxm/vol03-02/RXM003000202.pdf

Guitart, M. E., \& Rivas, M. J. (2008). La propuesta de las Universidades Interculturales en México frente al pluralismo cultural. El caso de Chiapas [The proposal of intercultural universities in Mexico against cultural pluralism. The case of Chiapas]. Documentación Social, 151, 147-162 (Online). Retrieved from http://www.caritas.es/imagesrepository/CapitulosPublicaciones/985/10\%20-\%20LA\%20PROPUESTA $\% 20$ DE\%20LAS\%20UNIVERSIDADES\%20INTERCULTURALES\%20EN\%20M\%C3\%89XICO\%20FRENT E\%20AL\%20PLURALISMO\%20CULTURAL.pdf

Hernández, R., Fernández, C., \& Baptista, M. P. (2014). Metodología de la Investigación (6th ed.). México, D.F.: McGraw-Hill/Interamericana Editores S.A de C.V.

Henry, C., Hill, F., \& Leitch, C. (2005). Entrepreneurship education and training: can entrepreneurship be taught? Part I. Education + Training, 47(2), 98-111. http://www.dx.doi.org/10.1108/00400910510586524

Hindle, K., \& Moroz, P. (2009). Indigenous entrepreneurship as a research field: Developing a definitional framework from the emerging canon. International Entrepreneurship and Management Journal, 6(4), 357-385. http://www.dx.doi.org/10.1007/s11365-009-0111-x 
Ho, R. (2014). Handbook of Univariate and Multivariate Data Analysis with IBM SPSS. Florida, USA: Taylor \& Francis Group, LLC.

Hofstede, G. (1980). Culture's Consequences: Comparing Values, Behaviors, Institutions and Organizations Across Nations (2nd ed.). Thousand Oaks, California: SAGE Publications, Inc.

Hofstede, G., Hofstede, G. J., \& Minkov, M. (2010). Cultures and Organizations: Software of the Mind. Intercultural Cooperation and Its Importance for Survival (3rd ed.). Nueva York, USA: McGraw-Hill.

Hunter, B. (2013). Recent growth in Indigenous self-employed and entrepreneurs (CAEPR working paper No. 91/2013). Retrieved from the website of the Australian National University, Centre for Aboriginal Economic Policy Research. Retrieved from http://caepr.anu.edu.au/Publications/WP/2013WP91.php

Instituto Nacional de Lenguas Indígenas (2009). Catálogo de las Lenguas Indígenas Nacionales. Variantes Lingüisticas de México con sus autodenominaciones y referencias geoestadísticas [Catalogue of National Indigenous Languages. Linguistic variants of Mexico with its self-denominations and geostatistical references]. México: INALI (in Spanish). Retrieved from http://site.inali.gob.mx/pdf/catalogo_lenguas_indigenas.pdf

Kets de Vries, M. F. R. (1985). The Dark Side of Entrepreneurship. Harvard Business Review, November Issue, 160-167. Retrieved from https://hbr.org/1985/11/the-dark-side-of-entrepreneurship

Kets de Vries, M. F. R. (1996). The Anatomy of the Entrepreneur: Clinical Observations. Human Relations, 49(7), 853-883. http://www.dx.doi.org/10.1177/001872679604900701

Lazear, E. P. (2005). Entrepreneurship. Journal of Labor Economics, 23(4), 649-680. Retrieved from http://www.dx.doi.org/10.3386/w9109

Lounsbury, M., \& Glynn, M. A. (2001). Cultural entrepreneurship: Stories, legitimacy, and the acquisition of resources. Strategic Management Journal, 22(6-7), 545-564. http://www.dx.doi.org/10.1002/smj.188

Marín, A. (2015). Financiamiento público para empresas indígenas en México [Public funding for indigenous companies in Mexico]. UPIICSA. Investigación Interdisciplinaria, 1(1), 52-81 (in Spanish). Retrieved from http://www.ruii.ipn.mx/index.php/RUII/article/view/8/pdf

McClelland, D. C. (1961). The Achieving Society. Princeton, N. J.: Van Nostrand Co.

McMullen, J. S. (2011). Delineating the Domain of Development Entrepreneurship: A Market-Based Approach to Facilitating Inclusive Economic Growth. Entrepreneurship Theory and Practice, 35(1), 185-193. $\mathrm{http}: / /$ www.dx.doi.org/10.1111/j.1540-6520.2010.00428.x

Morales, P. (2007). Estadística aplicada a las Ciencias Sociales. La fiabilidad de los tests y escalas [Statistics applied to Social Sciences. The reliability of the tests and scales]. Madrid, Spain (Book online, in Spanish). Retrieved from http://web.upcomillas.es/personal/peter/estadisticabasica/Fiabilidad.pdf

Morley, S. (2014). Closing the gap clearinghouse: Success factor for Indigenous entrepreneurs and community-based enterprises (Australian Institute of Health and Welfare, Resource sheet no. 30). Retrieved from http://www.aihw.gov.au/WorkArea/DownloadAsset.aspx?id=60129546986

Mueller, S., Volery, T., \& Von Siemens, B. (2012). What Do Entrepreneurs Actually Do? An Observational Study of Entrepreneurs' Everyday Behavior in the Start-Up and Growth Stages. Entrepreneurship Theory and Practice, 36(5), 995-1017. Retrieved from http://www.dx.doi.org/10.1111/j.1540-6520.2012.00538.x

Organización Panamericana de la Salud (2008). Una visión de salud intercultural para los pueblos indígenas de las Américas [A vision of intercultural health for indigenous peoples of the Americas]. Washington, D.C.: OPS (Serie OPS/FCH/CH/08/02.E). $\quad$ Retrieved from http://new.paho.org/hq/dmdocuments/2009/54-VisionSaludInterculturalPI.pdf

Peredo, A. M., \& Anderson, R. B. (2006). Indigenous Entrepreneurship Research: Themes and Variations. In C. S. Galbraith \& C. H. Stiles (Eds.), Developmental Entrepreneurship: Adversity, Risk, and Isolation (Book Series: International Research in the Business Disciplines, Volume 5, pp. 253-273). Oxford, UK: Emerald Group Publishing Limited.

Peredo, A. M., Anderson, R. B., Galbraith, C. S., Honig, B., \& Dana, L. P. (2004). Towards a theory of indigenous entrepreneurship. International Journal of Entrepreneurship and Small Business, 1(1/2), 1-20. http://www.dx.doi.org/10.2139/ssrn.1276522

Peredo, A. M., \& McLean, M. (2013). Indigenous Development and the Cultural Captivity of Entrepreneurship. 
Business \& Society, 52(4), 592-620. http://www.dx.doi.org/10.1177/0007650309356201

Petrakis, P. E., \& Kostis, P. C. (2014). Medium term effects of culture, transactions and institutions on opportunity entrepreneurship. Journal of Innovation and Entrepreneurship, 3(11), 1-22. http://www.dx.doi.org/10.1186/s13731-014-0011-3

Quintero, C. (2007). Generación de competencias en jóvenes emprendedores [Generation of skills in young entrepreneurs]. Bucaramanga, Colombia: Universidad Autónoma de Bucaramanga (in Spanish). Retrieved from http://www.usmp.edu.pe/facarrhh/primer_congreso_ippeu_boletin/ppts/Carlos_Quinteros.pdf

Radziszewska, A. (2014). Intercultural dimensions of entrepreneurship. Journal of Intercultural Management, 6(2), 35-47. http://www.dx.doi.org/10.2478/joim-2014-0010

Rodríguez, A., Sánchez, E., \& Estévez, E. (2011). Las mujeres emprendedoras en las comunidades indígenas [Women entrepreneurs in indigenous communities]. In F. J. García \& N. Kressova (Coords.), Actas del I Congreso Internacional sobre Migraciones en Andalucia (pp. 59-66). Granada, Spain: Instituto de Migraciones. Retrieved from https://dialnet.unirioja.es/servlet/articulo?codigo $=4030586$

Sandoval-Forero, E. A., \& Guerra-García, E. (2007). La interculturalidad en la educación superior en México [Interculturality in the higher education in Mexico]. Ra Ximhai, 3(2), 273-288. Retrieved from http://www.journals.unam.mx/index.php/rxm/article/view/6922/6442

Sautet, F. (2013). Local and Systematic Entrepreneurship: Solving the Puzzle of Entrepreneurship and Economic $\begin{array}{lllll}\text { Development. Entrepreneurship Theory and Practice, 37(2), 387-402. } & \text {. }\end{array}$ http://www.dx.doi.org/10.1111/j.1540-6520.2011.00469.x

Schmelkes, S. (2003). Educación intercultural. Reflexiones a la luz de experiencias recientes [Intercultural education. Reflections in the light of recent experiences]. Sinéctica, 23(2), 26-34 (in Spanish). Retrieved from https://sinectica.iteso.mx/ojs/index.php/SINECTICA/article/view/296/289

Schmelkes, S. (2013). Educación para un México intercultural [Education for an intercultural Mexico]. Sinéctica, 40(1), 1-12 (in $\quad$ Spanish). $\quad$ Retrieved from https://sinectica.iteso.mx/ojs/index.php/SINECTICA/article/view/48/40

Schumpeter, J. A. (1950). Capitalism, Socialism and Democracy ( $3^{\text {rd }}$ ed.). New York, USA: Harper \& Brothers.

Shane, S., \& Venkataraman, S. (2000). The Promise of Entrepreneurship as a Field of Research. Academy of Management Review, 25(1), 217-226. Retrieved from http://www.jstor.org/stable/259271

Tinoco, O. (2008). Medición de la Capacidad Emprendedora de ingresantes a la Facultad de Ingeniería Industria de la UNMSM [Measurement of the entrepreneurial capacity of new students to the Faculty of Industry Engineering of the UNMSM]. Industrial Data Revista de Investigación, 11(2), 18-23 (in Spanish). Retrieved from http://www.redalyc.org/articulo.oa?id=81619829003

Torres, J. R., \& Anderson, R. B. (2007). 'La Iguana Sana': An Aboriginal Entrepreneurial Endeavour in the Mexican State of Chiapas. In L.-P. Dana \& R. B. Anderson (Eds.), International Handbook of Research on Indigenous Entrepreneurship (pp. 413-418). Cheltenham, UK: Edward Elgar Publishing Limited. http://www.dx.doi.org/10.4337/9781781952641.00043

United Nations Educational, Scientific and Cultural Organization. (2013). Intercultural competences. Conceptual and Operational Framework. Paris, France: UNESCO. Retrieved from http://unesdoc.unesco.org/images/0021/002197/219768e.pdf

Venkataraman, S. (1998). The distinctive domain of entrepreneurship research. In J. A. Katz (Ed.), Advances in Entrepreneurship, Firm Emergence and Growth: Volume 3 (pp. 119-138). Wagon Lane, Bingley: Emerald Group Publishing Limited.

Westpac Group. (2014). Enabling Prosperity: Success Factors for Indigenous Economic Development (November 2014). Australia: Westpac Group/Urbis. Retrieved from https://www.westpac.com.au/docs/pdf/aw/Enabling_Prosperity_Success_Factors_for_Indigenous_Economi c_Development.pdf

World Bank. (1995). La enseñanza superior: las lecciones derivadas de la experiencia [Higher education: the lessons derived from the experience]. Washington, D.C.: World Bank (in Spanish). Retrieved from http://www-wds.worldbank.org/external/default/WDSContentServer/WDSP/IB/2005/06/14/000090341_20 050614161209/Rendered/PDF/133500PAPER0Sp1rior0Box2150A1995001.pdf

Yamada, J. I. (2004). A multi-dimensional view of entrepreneurship: Towards a research agenda on organisation 
emergence. Journal of Management Development, 23(4), 289-320. Retrieved from http://www.dx.doi.org/10.1108/02621710410529776

Yetim, N., \& Yetim, U. (2006). The Cultural Orientations of Entrepreneurs and Employees' Job Satisfaction: The Turkish Small and Medium Sized Enterprises (SMEs) Case. Social Indicators Research, 77(2), 257-286. http://www.dx.doi.org/10.1007/s11205-005-4851-x

\section{Appendix}

Table 3. One-way analysis of variance for the effects of the educational programs on entrepreneurial skills

\begin{tabular}{|c|c|c|c|c|c|}
\hline Educational programs & $M$ & $S D$ & $F(4,115)$ & $p$ & $\eta^{2}$ \\
\hline \multicolumn{6}{|l|}{ Self-knowledge } \\
\hline Tourism development & 3.87 & 0.52 & $2.45^{*}$ & .050 & .079 \\
\hline Sustainable rural development & 4.46 & 0.39 & & & \\
\hline Intercultural nursing & 3.88 & 0.78 & & & \\
\hline Language and culture & 4.07 & 0.76 & & & \\
\hline Intercultural communication & 4.04 & 0.58 & & & \\
\hline \multicolumn{6}{|l|}{ Vision of the future } \\
\hline Tourism development & 3.76 & 0.62 & 1.58 & .185 & .052 \\
\hline Sustainable rural development & 4.25 & 0.37 & & & \\
\hline Intercultural nursing & 3.81 & 0.78 & & & \\
\hline Language and culture & 3.89 & 0.56 & & & \\
\hline Intercultural communication & 4.04 & 0.46 & & & \\
\hline \multicolumn{6}{|l|}{ Achievement motivation } \\
\hline Tourism development & 3.88 & 0.54 & $2.79 *$ & .029 & .089 \\
\hline Sustainable rural development & 4.48 & 0.53 & & & \\
\hline Intercultural nursing & 4.02 & 0.69 & & & \\
\hline Language and culture & 4.25 & 0.47 & & & \\
\hline Intercultural communication & 4.12 & 0.52 & & & \\
\hline \multicolumn{6}{|l|}{ Planning } \\
\hline Tourism development & 3.86 & 0.64 & $2.55^{*}$ & .043 & .081 \\
\hline Sustainable rural development & 4.41 & 0.45 & & & \\
\hline Intercultural nursing & 3.93 & 0.64 & & & \\
\hline Language and culture & 4.13 & 0.52 & & & \\
\hline Intercultural communication & 4.04 & 0.51 & & & \\
\hline \multicolumn{6}{|l|}{ Persuasion } \\
\hline Tourism development & 3.32 & 0.63 & 1.13 & .346 & 0.38 \\
\hline Sustainable rural development & 3.81 & 0.49 & & & \\
\hline Intercultural nursing & 3.50 & 0.85 & & & \\
\hline Language and culture & 3.63 & 0.87 & & & \\
\hline Intercultural communication & 3.62 & 0.77 & & & \\
\hline
\end{tabular}

Note. Own elaboration. $N=120 .{ }^{*} p \leq .05$.

\section{Copyrights}

Copyright for this article is retained by the author(s), with first publication rights granted to the journal.

This is an open-access article distributed under the terms and conditions of the Creative Commons Attribution license (http://creativecommons.org/licenses/by/3.0/). 